\title{
PENGARUH FIRM SIZE DAN GROWTH PADA MANAJEMEN LABA
}

\author{
Laras Pangesti \\ Program Studi Akuntansi Fakultas Ekonomi Universitas Islam Batik \\ Surakarta, Indonesia \\ E-mail: laraslaras048@gmail.com
}

\begin{abstract}
This study aims to determine the effect of Firm Size and Growth on earnings management in manufacturing companies listed on the IDX. Quantitative research using 30 respondents and purposive sampling methods, namely (1) Manufacturing Companies that have been listed on the Indonesia Stock Exchange that have submitted audited financial statements and notes to the financial statements as of December 31, according to the research period. (2) Companies that submit complete data in accordance with the information needed, namely Firm Size, Growth and Profit Management. And using secondary data is the financial statements of manufacturing companies that meet the purposive sampling requirements that are analyzed using multiple linear regression with SPSS version 22. The results of this study indicate (1) Firm Size has a significant negative effect on earnings management, (2) Growth has no effect on profit management. Benefits of research, (1) For practitioners, input for investors in investing in the capital market is also a reference to make a healthy company with this research. (2) For Theoretical, Add insight into Firm Size, Growth and Earnings Management.
\end{abstract}

Keywords : Firm, Size, Growth, Management, Profit 
PENDAHULUAN

Mengelola laba dilakukan dengan cara memanipulasi akrual tanpa mempengaruhi aliran kas (manajemen laba akrual), dan dengan aktivitas nyata yang mempengaruhi aliran kas perusahaan (manajemen laba riil), serta bersifat oportunistik yaitu keputusan-keputusan yang diambil oleh manajer akan menguntungkan pihak manajer sendiri, juga bersifat efisien dan informatif yaitu keputusan manajer cenderung menguntungkan pihak pemegang saham (Yudanto dan Ratnaningsih, 2012:2)

Penelitian yang dilakukan oleh Mahiswari dan Nugroho, 2014 menujukkan bahwa Firm Size berpengaruh terhadap manajemen laba karena menentukan banyak sedikitnya praktik manajemen laba dalam perusahaan. Dilihat dari meningkatnya firm size diikuti meningkatnya kebutuhan dana untuk pembiayaan ekspansi. Joni dan Lina (2010) juga berpendapat bahwa pertumbuhan perusahaan menggambarkan bagaimana menginvestasikan dana yang dimiliki perusahaan untuk kegiatan operasi dan investasi.
Rumusan masalah dalam penelitian ini adalah :(1).Apakah pengaruh Firm Sizeterhadap manajemen laba? (2). Apakah pengaruh Growth terhadap manajemen laba?. Penelitian ini bermanfaat: (1). Bagi Akademisi, dapat menambah dan memberikan pengetahuan yang berkaitan dengan pengaruhFirm Size,Growth, Kualitas Audit Terhadap Manajemen Laba. (2). Bagi praktisi, masukan untuk investor dalam berinvestasi di pasar modal juga acuan untuk menjadikan perusahan yang sehat dengan adanya penelitian ini.

\section{TINJAUAN PUSTAKA}

\section{Teori Agensi}

Teori agensi menjelaskan hubungan kerja antara pemilik perusahaan dan manajemen. Disebut Manajemen yaitu agen yang ditunjuk oleh pemegang saham dan diberi tugas serta wewenang mengelola perusahaan atas nama pemegang saham. Pihak principal termotivasi mengadakan kontrak untuk menyejahterakan dirinya melalui pembagian dividen atau kenaikan harga saham perusahaan. Agent termotivasi untuk meningkatkan kesejahteraannya 
melalui peningkatan kompensasi. ekonomi perusahaan atau untuk Konflik kepentingan semakin mempengaruhi hasil perjanjian yang meningkat ketika principal tidak tergantung pada angka-angka memiliki informasi yang cukup akuntansi yang dilaporkan.

tentang kinerja agent karena

Schipper (2000) dalam Sumomba ketidakmampuan principal memonitor aktivitas agent dalam perusahaan. Sedangkan agent mempunyai lebih banyak informasi mengenai kapasitas diri, lingkungan kerja, dan perusahaan secara keseluruhan.

\section{Manajemen Laba}

Manajemen laba adalah tindakan manajer untuk menaikkan atau menurunkan laba periode berjalan dari sebuah perusahaan yang dikelolanya tanpa menyebabkan kenaikkan (penurunan) keuntungan ekonomi pemsahaan jangka panjang (Rosenzweig dan Fischer, 1994 dalam Sumomba 2010). Rosenzweig dan Fischer (1994) mengungkapkan bahwa manajemen laba terjadi ketika manajer menggunakan pertimbangan (judgement) dalam pelaporan keuangan dan penyusunan transaksi untuk merubah laporan keuangan, dengan tujuan untuk memanipulasi besaran (magnitude) laba kepada beberapa stakeholders tentang kinerja (2010) mendefinisikan manajemen laba sebagai suatu intervensi manajemen dengan sengaja dalam proses penentuan laba guna memperoleh beberapa keuntungan pribadi. Maksud dari intervensi di sini adalah upaya yang dilakukan oleh manajer untuk mempengaruhi informasi-informasi dalam laporan keuangan dengan tujuan untuk mengelabui stakeholders yang ingin mengetahui kinerja dan kondisi perusahaan. Sering kali proses ini mencakup mempercantik laporan keuangan (fashioning accounting reports), terutama angka yang paling bawah, yaitu laba (Wild et al., 2004).

\section{Firm Size}

Firm Size adalah skala perusahaan yang dilihat dari total aktiva perusahaan pada akhir tahun. Total penjualan juga dapat digunakan untuk mengukur besarnya perusahaan (Veronica dan Siddharta, 2005). Firm Size menggambarkan besar kecilnya 
perusahaan. Besar kecilnya usaha tersebut ditinjau dari lapangan usaha yang dijalanakan. Penentuan skala besar kecilnya perusahaan dapat ditentukan berdasarkan total penjualan, total asset, rata-rata tingkat penjualan (Seftianne, 2011).

Perusahaan yang berukuran besar mempunyai berbagai kelebihan dibanding perusahaan berukuran kecil. Kelebihan tersebut yang pertama adalah Firm Size dapat menentukan tingkat kemudahan perusahaan memperoleh dana dari pasar modal. Kedua, Firm Size menentukan kekuatan tawar-menawar (Bargaining Power) dalam kontrak keuangan. Dan ketiga, ada kemungkinan pengaruh skala dalam biaya dan return membuat perusahaan yang lebih besar dapat memperoleh lebih banyak laba (Sawir, 2004) dalam (Oktavianti, 2015).Firm Size dapat menentukan banyak sedikitnya praktik manajemen laba sebuah perusahaan (Mahiswari dan Nugroho, 2014:6). Jao (2011:46) mengatakan bahwa Firm Size memiliki pengaruh negatif terhadap manajemen laba karena perusahaan yang besar lebih diperhatikan oleh masyarakat.

\section{Growth}

Pertumbuhan

perusahaan (company growth) adalah peningkatan atau penurunan total aset yang dimiliki oleh perusahaan. Pertumbuhan perusahaan dihitung sebagai persentase perubahan aset pada tahun tertentu terhadap tahun sebelumnya (Suprantiningrum, 2013). Menurut Brigham dan Houston (2009) pertumbuhan perusahaan adalah perubahan (peningkatan atau penurunan) total aset yang dimiliki oleh perusahaan. Joni dan Lina (2010) yang berpendapat bahwa pertumbuhan perusahaan pada dasarnya menggambarkan bagaimana perusahaan menginvestasikan dana yang ia miliki untuk kegiatan operasi dan investasi. Peningkatan jumlah aset, baik aset lancar maupun aset jangka panjang membutuhkan dana, dengan alternative pendanaan internal atau dengan pendanaan eksternal.

\section{Penelitian Sebelumnya}

Penelitian yang dilakukan oleh Philmore dan Broome (2010) yang menyatakan bahwa norma subjektif adalah prediktor yang paling penting untuk memprediksi intensi investor 
dalam berinvestasi saham. Hasil Penelitian Susilowati (2017) menyatakan bahwa salah satu faktor yang mempengaruhi minat mahasiswa akuntansi untuk berinvestasi di pasar modal adalah persepsi return. Sejalan dengan hasil penelitian tersebut, Tandio dan Widanaputra (2016) menemukan bahwa return berpengaruh positifterhadapminat investasi. Hilgert et al (2003) mengemukakan bahwa seseorang yang memiliki literasi keuangan (financial literacy) yang baik memiliki tanggung jawab yang lebih baik secara keuanganMenurut penelitian yang dilakukan oleh Al-Tamimi (2009), menunjukkan adanya hubungan yang signifikan antara financial literacy dan keputusan investasi pada investor United Arab Emirates. Berbeda dengan penelitian yang dilakukan oleh Ariani (2015) yang menyatakan bahwa literasi keuangan tidak berpengaruh secara signifikan terhadap keputusan investasi.

Firm Size berpengaruh terhadap Manajemen Laba

Penelitian yang dilakukan oleh Dewi Kusuma Wardani dan Desifa
Kurnia Santi (2018) mengemukan bahwa Firm Size berpengaruh dan signifikan terhadap manajemen laba. Hal ini menunjukan bahwa Perusahaan yang lebih besar kurang termotivasi untuk melakukan manajemen laba, karena mereka dituntut untuk menyajikan laporan keuangan yang baik guna memenuhi ekspektasi pemegang saham (Prasetya, 2015:533), hal ini terjadi karena pemegang saham dan pihak luar di perusahaan besar dianggap lebih kritis dibandingkan dengan perusahaan kecil.

H1: Firm Size (X1) berpengaruh terhadap Manajemen Laba (Y).

\section{Growth berpengaruh terhadap Manajemen Laba.}

Penelitian yang dilakukan oleh Arla Aulia Annisa dan Dody Hapsoro (2017) mengemukan bahwa Growth berpengaruhdan signifikan terhadap manajemen laba. Hal ini menunjukkan bahwa perusahaan yang mengalami pertumbuhan memiliki kecenderungan untuk menaikkan laba dengan tujuan untuk menarik perhatian investor agar 
tetap menginvestasikan dananya pada perusahaan.

H2: Growth (X2) berpengaruh terhadap Manajemen Laba(Y).

\section{METODE PENELITIAN}

Penelitian ini menggunakan penelitian kausal komparatif. Menurut Sugiyono (2013:37) hubungan kausalitas ialah hubungan bersifat sebab akibat antara variabel independen (variabel yang mempengaruhi) dan variabel dependen (variabel yang dipengaruhi). Sedangkan berdasarkan jenis datanya, penelitian ini tergolong penelitian kuantitatif yaitu data yang digunakan berbentuk angka.

Variabel independen adalah Manajemen Laba, dalam penelitian ini manajemen laba diproksikan dengan menggunkan discretionary accrual (DAC) yang merupakan perhitungan model Jones modifikasian (modified jones model 1991 dalam Wardani \&
Kusuma, 2012.Variabel dependennya adalah Firm Size dangrowth. Data penelitian ini menggunakan perusahaan manufaktur yang terdaftar di Bursa Efek Indonesia (BEI). Periode pengamatan yang digunakan adalah antara tahun 2014-2018 kemudian diolah dengan menggunakan beberapa uji statistik, yaitu (1) Uji statistik deskriptif, (2) Uji asumsi klasik yang terdiri dari uji normalitas, uji multikolinieritas, dan uji heteroskedastisitas, Uji hipotesis yang terdiri dari uji regresi linier berganda dan uji koefisien determinasi. Populasi dalam penelitian ini adalah perusahaan manufaktur yang sudah terdaftar di Bursa Efek Indonesia (BEI). Teknik pengambilan sampel yang digunakan di dalam penelitian ini adalah metode purposive sampling.

\section{HASIL DAN PEMBAHASAN}

Tabel 1. Data Penelitian

\begin{tabular}{|c|c|c|c|c|c|}
\hline No. & $\begin{array}{c}\text { NAMA } \\
\text { PERUSAHAAN }\end{array}$ & TAHUN & & $\begin{array}{c}\text { NAMA } \\
\text { PERUSAHAAN }\end{array}$ & TAHUN \\
\hline 1 & $\begin{array}{l}\text { ASTRA } \\
\text { INTERNASIONAL }\end{array}$ & 2014 & 16 & Indofood & 2015 \\
\hline 2 & & 2015 & 17 & & 2016 \\
\hline 3 & & 2016 & 18 & & 2017 \\
\hline 4 & & 2017 & 19 & Garuda Metalindo & 2015 \\
\hline
\end{tabular}




\begin{tabular}{|c|c|c|c|c|c|}
\hline 5 & & 2018 & 20 & & 2016 \\
\hline 6 & Uniever & 2015 & 21 & & 2017 \\
\hline 7 & & 2016 & 22 & Gudang Garam & 2016 \\
\hline 8 & & 2017 & 23 & & 2017 \\
\hline 9 & & 2018 & 24 & Holcim Indonesia & 2014 \\
\hline 10 & Kimia Farma & 2014 & 25 & & 2015 \\
\hline 11 & & 2015 & 26 & & 2016 \\
\hline 12 & & 2016 & 27 & & 2017 \\
\hline 13 & & 2017 & 28 & Multipular & 2015 \\
\hline 14 & & 2018 & 29 & & 2016 \\
\hline 15 & Indofood & 2014 & 30 & & 2017 \\
\hline
\end{tabular}

Tabel 2. Hasil Uji Normalitas

Tabel 3. Hasil Multikolinieritas

Kolmogrov Smirnov

\begin{tabular}{|l|l|l|l|c|c|}
\hline \multicolumn{1}{|c|}{ Variabel } & Tolerance & Kriteria & VIF & Kriteria & keterangan \\
\hline Firm Size & 0,989 & $>0.1$ & 1,011 & $<10$ & $\begin{array}{c}\text { tidak ada } \\
\text { multikolinieritas }\end{array}$ \\
\hline Growth & 0,989 & $>0.1$ & 1,011 & $<10$ & $\begin{array}{c}\text { multikolinieritas } \\
\text { tidak ada } \\
\end{array}$ \\
\hline
\end{tabular}

Sumber : lampiran

Tabel 4. Uji Autokorelasi

\begin{tabular}{ccccccc}
\hline DW & DL & DU & 4-DL & 4-DU & Kriteria & Keputusan \\
\hline 1,613 & 1,1284 & 1,567 & 2,786 & 2,716 & DU<DW<4-DU & $\begin{array}{c}\text { Tidak Terjadi } \\
\text { Autokorelasi }\end{array}$ \\
\hline
\end{tabular}

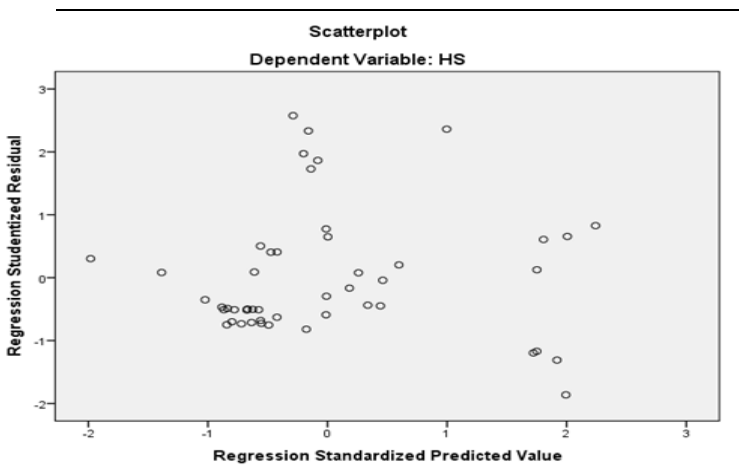

Tabel 2.4 Uji Heteroskedastisitas 
Tabel 3.1 Model Regresi

\begin{tabular}{lcc}
\hline \multicolumn{1}{c}{ Model } & B \\
\hline (Constant) & 2,936 \\
FIRM_SIZE &,- 540 \\
Growth &,- 080 \\
\hline
\end{tabular}

Sumber : Lampiran

$\mathrm{Y}=2,936-0,540-0,080$

Tabel 5. Hasil Uji Regresi Linier Berganda

\begin{tabular}{|l|r|r|r|r|c|}
\hline \multicolumn{1}{|c|}{ Hipotesis } & $\begin{array}{c}\text { Nilai t } \\
\text { hitung }\end{array}$ & T tabel & \multicolumn{1}{c|}{ Sign } & Kriteria & keterangan \\
\hline Firm Size & $-2,387$ & 2,052 & .025 & $<0.05$ & diterima \\
\hline Growth & $-0,228$ & 2,052 & .822 & $<0.05$ & ditolak \\
\hline & & & & & \\
\hline
\end{tabular}

Tabel 6. Uji F

\begin{tabular}{lcccccc}
\hline F hitung & F tabel & Sig & Syarat & \multicolumn{2}{l}{ Kesimpulan } & \\
\hline 3,828 & 3,354 & 0,01 & $<0,05$ & \multicolumn{2}{c}{ Model Layak } & \\
\hline & Sumber : Lampiran & Tabel & 7. & Hasil uji & koefisien \\
& & & determinasi & &
\end{tabular}

\begin{tabular}{|c|c|l|}
\hline Model & R2 & \multicolumn{1}{|c|}{ Keterangan } \\
\hline 1 & .173 & $\begin{array}{l}\text { Firm Size dan Growth sebesar 17,3\%, sisanya yaitur 82,7\% } \\
\text { dijelaskan oleh variabel lain diluar model penelitian ini }\end{array}$ \\
\hline
\end{tabular}

Sumber : lampiran

PEMBAHASAN

Pengaruh Firm Size terhadap

Manajemen Laba

Firm Size berpengaruh negatif dan signifikan terhadap manajemen laba. Pernyataan tersebut terdukung oleh hasil $\mathrm{t}$ hitung $>\mathrm{t}$ table serta tingkat signifikansi 0,025. Perusahaan yang terdaftar di BEI ialah perusahaan yang cukup besar, mereka cenderung 
kurang termotivasi melakukan manajemen laba, disebabkan tuntutan untuk menyajikan laporan keuangan yang baik untuk memenuhi ekspektasi pemegang saham. Pemegang sahampihak luar di perusahaan besar akan lebih kritis. Hasil penelitian ini sesuai dengan penelitian yang dilakukan oleh Prasetya (2015:533) Jao (2011:46) bahwa terdapat hubungan negatif antara Firm Size dan manajemen laba. Hasil penelitian ini bertentangan dengan hasil penelitian yang dilakukan oleh Desmiyawati et al(2009:188) menyatakan Firm Size berpengaruh secara positif terhadap manajemen laba..

\section{Pengaruh Growth (Pertumbuhan)} terhadap terhadap Manajemen Laba

Growth tidak berpengaruh terhadap manajemen laba. Pernyataan tersebut terdukung oleh hasil $\mathrm{t}$ hitung sebesar -2,387 dan tingkat signifikansi 0,822 . Hal ini berarti, pertumbuhan perusahaan tidak berkontribusi terhadap manajemen laba.Salah satu hal yang dapat memicu manajer untuk melakukan manajemen laba adalah keinginan untuk meminimalkan risiko politik (Scott, 1997: 303). Hipotesis political cost menyatakan perusahaan yang berhadapan dengan biaya politik cenderung untukmelakukan rekayasa penurunan laba dengan tujuan untuk meminimalkan biaya politik yang harus mereka tanggung.Terkait dengan political cost tersebut, AlNajjar dan Belkaoui (2001) menemukan hal yang menarik, yaitu perusahaan dengan tingkat pertumbuhan yang tinggi juga memiliki motivasi untuk meminimalkan laba. Tingkat pertumbuhan yang tinggi ditandai dengan tingginya tingkat set kesempatan investasi (investment opportunity set/IOS) akan tercermin dalam tingginya tingkat profitabilitas perusahaan (Saputro dan Setiawati, 2004). Tingkat profitabilitas yang tinggi dapat dibaca oleh pihak regulator dan pihak lain sebagai tingkat laba yang terlalu tinggi dan dapat memicu tuntutan yang tinggi terhadap perusahaan sehingga menimbulkan kecurigaan adanya monopoli. Indikasi monopoli akan menyebabkan perusahaan berhadapan dengan regulator (Cahan, 1992; Na'im dan Hartono, 1996). Penelitian AlNajjar dan Belkaoui (2001) 
membuktikan bahwa perusahaan dengan IOS yang tinggi atau perusahaan yang memiliki peluang pertumbuhan yang tinggi akan melakukan rekayasa penurunan laba atau manajemen laba.

\section{KESIMPULAN}

Populasi dalam penelitian ini adalahperusahaan manufactur yang terdaftar di Bursa Efek Indonesia (BEI). Teknik pengambilan sampel yang digunakan adalah metode purposive sampling sejumlah 30 responden.Menggunakandata

sekunder yaitu laporan keuangan persahaan manufaktur dan dianalisis menggunakan analisis regresi linier berganda dengan program SPSS versi 22.0.

Berdasarkan hasil dan
pembahasan di atas, maka
disimpulkan bahwa variabel Firm Size berpengaruh negatif terhadap manajemen laba. Hasil penelitian ini sejalan penelitian yang dilakukan oleh Dewi Kusuma Wardani dan Desifa Kurnia Santi (2018) mengemukan bahwa Firm Size berpengaruh negatif dan signifikan terhadap manajemen laba. Growth tidak berpengaruh terhadap manajemen laba. Beberapa keterbatasan dalam penelitian ini sangat berguna bagi penelitian selanjutnya untuk memperoleh hasil yang jauh lebih baik, antara lain : (1) Keterbatasan dalam memperoleh responden. Peneliti hanya menggunakan $30 \quad$ responden(2) Penggunaan model untuk mendeteksi terjadinya manajemen laba dalam penelitian ini belum mampu mendeteksi manajemen laba dengan baik atau tepat. Oleh karena itu, dalam penelitian selanjutnya dapat mempertimbangkan penggunaan model yang berbeda dalam menentukan discretionary accrual, sehingga dapat melihat manajemen laba dengan sudut pandang. Saran hasil penelitian diharapkan sebagai berikut: (1) Bagi Peneliti Selanjutnya,dapat memperluas populasi, dapat menambah variabelvariabel bebas lainnya yang memiliki pengaruh terhadap manajemen laba. (2)Bagi Investor, disarankan untuk tidak hanya memperhatikan return dan risiko investasi saja, namun juga memperhatikan faktor lain seperti faktor fundamental dan faktor teknikal dalam berinvestasi saham di pasar 
modal.(3) Bagi Bursa Efek Indonesia (BEI), disarankan untuk lebih gencar lagi dalam melakukan sosialisasi atau penyuluhan mengenai investasi saham ke universitas yang tersebar di seluruh Indonesia, sehingga dapat meningkatkan jumlah investor muda yang akan melakukan investasi saham.

\section{DAFTAR PUSTAKA}

Al-Najjar, F. \&.-B. (2001). Growth Opportunities and Earnings Management. Managerial Finance, 72-81.

Desmiyawati. (2009). Pengaruh Asimetri Informasi dan Firm Size terhadap Praktik Manajemen Laba pada

Perusahaan Manufaktur yang Terdaftar di Bursa Efek Indonesia. Pekbis Jurnal , Vol.1, No.3, 180-189.

Gayatri. (2016). Implikasi Firm Size dan Pengungkapan Corporate Social Responsibility terhadap Manajemen Laba. Bisnis dan Manajemen, Vol. 4, No 2, 4.

Jao, R. a. (2011). Corporate Governance, Firm Size, dan Leverage Terhadap Manajemen Laba Perusahaan Manufaktur di
Indonesia. Jurnal Akuntansi dan Auditing , 43-54.

Kurniawati, \&. F. (2009). Pengaruh Asimetri Informasi dan Kualitas Auditor Terhadap Manajemen Laba pada Perusahaan yang Bergerak di Sektor Keuangan yang Terdaftar di BEI. Jurnal Ekonomi .

Kusuma, \&. a. (2014). Analisis Pengaruh Corporate Social Responsibility terhadap Kinerja Keuangan Perusahaan dengan Manajemen Laba Sebagai Variabel Pemoderasi.

Diponegoro Journal of Accounting, Vol. 3, No 1, 1-13. Michael, J. C. (1976). Theory of the Firm: Managerial Behavior, Agency Costs and Ownership Structure. Journal of Financial Economics, Vol. 3, No. 4, 305360.

Prasetya, \&. J. (2015). Pengaruh Firm Size terhadap Manajemen Laba dengan Pengungkapan Corporate Social Responsibility Sebagai Variabel Intervening. EJurnal Akuntansi Universitas Udayana, Vol. 14, No 1, 511538. 
Rusmin. (2010). Auditor Quality and Earnings Management Singapore Evidence. Managerial Auditing Journal, Vol. 25, 618-638.

S, M. (2011). Analisis Faktor-Faktor yang Berpengaruh Terhadap Manajemen Laba (Studi pada Perusahaan Perbankan yang
Terdaftar di Bursa Efek Indonesia periode tahun 20062008). Doctoral dissertation .

Saputro, A. J. (2004). Kesempatan Bertumbuh dan Manajemen Laba: Uji Hipotesis Political Cost. Jurnal Riset Akuntansi Indonesia , 251-263. 